\title{
Ageing Care Centre Women Entrepreneur: A Silver Bullet for Ageing Tsunami in Malaysia
}

\author{
Shaista Noor ${ }^{*}$, Filzah Md. Isaa, Leilanie Mohd Nor ${ }^{b}$ \\ ${ }^{a}$ Faculty of Business, Taylors University, Selangor Darul Ehsan, Malaysia \\ ${ }^{b}$ Bina Pavo Family Business Institute, Selangor, Malaysia \\ *Corresponding author: shaistanoor@sd.taylors.edu.my
}

Article history: Received:06 Mac 2019 Received in revised form: 23 July 2019 Accepted: 20 August 2019 Published online: 31 December 2019

\begin{abstract}
An ageing population is a global problem, and it affects all aspects of life. Globally, a drastic increase in the elderly population has been recorded, which is almost three times from the year 1980 (259 million) to 2025 (761 million). Similar trend also takes place in Malaysia, even though Malaysia is categorized as a developing country. Its population census reported an intense increase in ageing population from the year 2005 (7\%), which is expected to be double $(14 \%)$ by the year 2028. In addition, women comprise about half of the population in Malaysia. Thus, the Malaysian Government has acknowledged the importance of women entrepreneurs in the country's economic growth. The report estimates that $20 \%$ of the entire registered business in Malaysia run by women, and about 650,000 women are engaged in various business activities. Currently, there are about 365 ageing care centres in Malaysia, and women entrepreneurs run a few of them, as sole ownership or partnership. The Malaysian Government is gradually facing the worrisome situation of dealing with the ageing population, as until the year 2030, Malaysia will be in the line of ageing group countries. Due to ageing population importance, this study inquires the situation of Malaysian women as ageing care centre entrepreneur, and ageing population issues in Malaysia. To gather the information, the qualitative research strategy, and semi-structured interviews technique was chosen for data collection. The target population of this study are five women entrepreneurs of ageing care centres in Malaysia. The findings highlight the social problems of elderly and difficulties of Malaysian women entrepreneur in care centre business such as funding, licensing issues, less technology, staff retention, and lack of trained staff. The results show that successful entry of womenfolk in ageing care centres business will bring significant social change and will help the government to overcome the challenge of the ageing population. This study will help the policymakers to formulate strategies for women entrepreneurship in Malaysia, especially the care centres entrepreneurs. Hence, the women can act as a silver bullet to subside the ageing tsunami that will crash Malaysians' social life comfort.
\end{abstract}

Keywords: Ageing population; women; entrepreneur; business; care centres; elderly

\begin{abstract}
Abstrak
Penuaan populasi adalah suatu masalah global, dan ia mempengaruhi semua aspek kehidupan. Secara global, peningkatan drastik dalam populasi warga tua telah mencatatkan penambahan hampir tiga kali ganda jumlah dari tahun 1980 (259 juta) ke tahun 2025 (761 juta). Tren yang serupa juga berlaku di Malaysia, meskipun Malaysia dikategorikan sebagai sebuah negara yang sedang membangun. Bancian penduduk melaporkan peningkatan yang ketara dalam populasi dari tahun 2005 (7\%), dan dijangka akan meningkat dua kali ganda (14\%) menjelang tahun 2028. Selain itu, wanita terdiri daripada separuh penduduk di Malaysia. Justeru, kerajaan Malaysia telah mengiktiraf kepentingan usahawan wanita dalam pertumbuhan ekonomi negara. Laporan berkaitan menganggarkan bahawa $20 \%$ daripada keseluruhan perniagaan berdaftar di Malaysia dikendalikan oleh kaum wanita, justeru, dan anggaran 650,000 wanita terlibat dalam berbagai kegiatan perniagaan. Pada masa kini, terdapat lebih kurang 365 pusat penjagaan warga tua di Malaysia, dan usahawan wanita mengendalikan sebahagian kecil pusat-pusat tersebut, samada sebagai pemilik tunggal atau secara perkongsian. Kerajaan Malaysia kini semakin lama semakin kerap berhadapan dengan situasi yang membimbangkan dalam menangani isu penuaan populasi, di mana sehingga tahun 2030, Malaysia dijangka berada sebaris dengan kumpulan negara yang mempunyai ramai penduduk yang berumur lanjut. Disebabkan kepentingan penuaan populasi, kajian ini cuba meneliti situasi wanita Malaysia sebagai usahawan pusat penjagaan warga tua, dan isu-isu berkaitan populasi warga tua. Untuk mengumpul maklumat, strategi penyelidikan kualitatif dan teknik wawancara separuh berstruktur telah dipilih bagi pengumpulan data. Sasaran populasi kajian ini adalah lima usahawan wanita pusat penjagaan warga tua di Malaysia. Penemuan kajian menyerlahkan masalah sosial warga tua dan kesukaran yang dihadapi oleh wanita Malaysia dalam menguruskan perniagaan pusat penjagaan seperti; pembiayaan, isu pelesenan, kekurangan teknologi, pengekalan kakitangan, dan kekurangan tenaga terlatih. Keputusan kajian menunjukkan bahawa kejayaan penglibatan wanita dalam perniagaan pusat penjagaan warga tua akan membawa perubahan sosial yang penting dan akan membantu kerajaan untuk mengatasi cabaran berkaitan penuaan populasi. Kajian ini akan membantu penggubal dasar merangka strategi untuk aktiviti keusahawanan wanita di Malaysia, terutamanya usahawan yang menguruskan pusat penjagaan. Justeru, wanita boleh bertindak sebagai "peluru perak" untuk meredakan tsunami penuaan populasi yang bakal menggugat keselesaan kehidupan sosial warga negara Malaysia.
\end{abstract}

Kata kunci: penuaan populasi; wanita; usahawan; perniagaan; pusat penjagaan; warga tua 


\subsection{INTRODUCTION}

The ageing population is a worldwide phenomenon, and it affects all facets of human life. The ageing population is more evident since the last few decades in developed countries, as compared to developing nations. The estimates show that until the year 2050 , the world population will rise to $8-9.6$ billion. Hence, the ageing population is considered as a significant challenge for various European countries all across the globe in the upcoming next fifty years (WHO, 2012; Burton et al., 2016). However, ageing population implications for the socioeconomic system, such as pension program, medical and kinship are likely to be substantial. Nowadays, the ageing population is becoming a challenge all across the globe as estimates show that $72 \%$ of this worldwide population is residing in developing countries (Fausset et al., 2011; Fatimah et al., 2014).The ageing occurs when the older population of any country touches $7 \%$ of the entire population. The United Nations report revealed that the ageing population would become double in major industrialised countries all across the globe within the next fifty years (UN, 2016). As Chawla et al., (2007) and Lee et al., (2012) pointed out that ageing directly affects the economic growth, and it is linked with governmental policies and variations input. The National Council for Senior Citizen Organisation Malaysia (NASSCOM) reported an increase of ageing population in Malaysia. In a similar vein, United Nation Statistic Division (2005) reported the count of male aged population 900550 whereas female elderly counted as 873810 out of 1.77 million of the total ageing population all across the globe. The elderly population is a mixed community and are suffering from various health and nonhealth factors altogether. Hence, the aged population requires housing, well equipped with technological advancement, specifically in terms of health care, and needs a home with comfort, freedom, and easy access to friends and family. The four significant facts associated with the elderly population are age, poverty, isolation, and dementia (Ong et al., 2009; Ursulica, 2016). Past researches show a drastic rise in the elderly population in the UK, as in the year 2007 recorded 9.8 million people age above 65 , whereas by the year 2023 it is expected to be 16.1 million. In different continents, for instance in Latin America, the elderly population reaches to $71 \%$ followed by $66 \%$ increase in Asian countries, and 64\% rise accounted in the African region, while $41 \%$ in North America (NPE, 2015; Soong et al., 2016). All across the globe, the family is responsible for elderly care, and it is wrong to say that developing nation families are only responsible for elderly care, same is the case with developed nation, whereby families are considered as leading support providers of disabling elderly (Hock et al., 2012). The Ministry of Health of Malaysia reported that the government had fixed $8.39 \%$ of the National Budget that is about RM 22.16 billion for health care facilities improvement. According to the report of an American publication, International Living, Malaysian health care system is listed as third among 24 countries. However, due to increased elderly persons, medication cost has grown along with better technological advancement in medical science (Soon, 2015). In this regard, Guerin et al. (2015) stated that although the health care system in Malaysia is satisfactory, still issues regarding affordability and quality is getting worse with time. This is due to increase in aged population, and existing care centres in the country are facing difficulties in selection of a suitable caregiver, untrained staff, lack of accessing criteria of elderly condition before admission, lack of workforce in centres, and weak infrastructure. Ultimately, the most important thing is to give a quality life to the elderly (Samad et al., 2017; ACP, 2018). Undoubtedly, it is a big challenge for Malaysia to manage an ageing society, as until the year 2028, Malaysia will be in the list of ageing population countries like many developed countries. The question is how fully the state is prepared to overcome the tsunami of ageing.

\subsection{LITERATURE REVIEW}

\subsection{Ageing Care Centres}

The percentage of the population aged 60 and above, has shown an increase over the years as it was 5.2\% in 1970, 5.7\% in 1990, and 6.3\% in 2000, and it is expected to be $9.8 \%$ in 2020. Thus, from 1990 to 2020, there is a remarkable increase in the elderly population in Malaysia that is almost $80 \%$ (Kumar. 2014; Olivia et al., 2016; Aini et al., 2017). Hence, due to the increase in the ageing population, the life span of the ageing population is also expanding, as women live longer as compared to men, and the aged population is growing in urban areas as compared to rural areas, which can be due to increase mobility of job seekers (Farber at al., 2011). The National Population and Family Development Board Malaysia (2011) reported a rise of about 7 million or $17.6 \%$ of the expected population of 40 million by the year 2040. Presently, the total population of aged 60 and above in Malaysia is estimated to be around 1.4 million, and it is expected to increase to 3.3 million until 2020 (Lee et al., 2012, ACP, 2018). This situation is quite worrisome, and awareness campaigns regarding the ageing population challenges and elderly care are needed. At present, infrastructure and health care facilities for the elderly population is lacking all across the globe including Malaysia (NPFE, 2015). Nevertheless, elderly care centres are increasing all across the globe, and the government of developed countries such as USA, UK, Germany, Finland, and Ireland are paying more attentions to build more health centres and elderly care centres. The developing countries such as India, Pakistan, Singapore, Indonesia and Malaysia are also striving hard to improve the ageing care centres in their respective countries. Currently, in Malaysia, three types of elderly care centres are working to serve this elderly segment; centres that are funded by the government, supported by NGO's, and run by private sector. Regardless, services provided by these ageing care centres are not up to mark in term of technology, health care services and equipment. Therefore, the elderly residing in these centres may face emotional, health, and some to certain extent are suffering mental disorders (Tohit et al., 2012; Rashid et al., 2015).

\subsection{Sustainability Of Ageing Care Centres In Malaysia}

In Malaysia, the majority of elderly from villages moved to cities with children as a result of growth and development. Like other Asian countries, the trend of joint family set up in Malaysia is changing to nuclear family. It is a worldwide fact that mental and physical ability deteriorates with age. Sometimes, children feel it is challenging to take care of ageing parents because of their busy life and daily routine. Either voluntary or involuntary, they may send their elderly parent to any ageing centre for better care and treatment. Due to increasing demand for elderly care service, there is a need for more and better-equipped elderly centres throughout the country. Hence, responsibility comes on the shoulder of the public and private sector to fulfill the demand of elderly care centres (Ong et al., 2009; Akil et al., 2014). To 
cater to this segment effectively, Malaysia requires proper enhanced coordination and communication at all levels of administration in policy development. The private sector must also involve partners in this regard. To enhance the care for the ageing population, the Malaysian government has formulated a National Policy for the elderly under the Ministry of Women, Family and Community Development for the well-being of elderly population in terms of financial assistance, day care centre for older persons, homes for older persons without next of kin, and national celebration day for older persons. Malaysia has established the old home in such a way that is quite difficult to recognise the social policy jigsaw for elderly housing. The policy means that which specific strategic planning to be followed to achieve the goals in a challenging environment (Bauer et al., 1998). Prior researches show that the private sector are actively participating in Malaysia for ageing care centre, although, social policy and housing policy are interlinked with each other and considered the same universally. The infrastructure of an ageing care centre in Malaysia is directly linked with the housing policy approach (Suleiman et al., 2005; Yusuf et al., 2004). Earlier, Peace (2002) had pointed out the housing-related need for elderly homes such as support, security, adaptability, care, social obligations, communication and group housing for people after retirement age. These factors are crucial for the comfort of elderly population in world, and the factors are depicted in Figure 1 below.

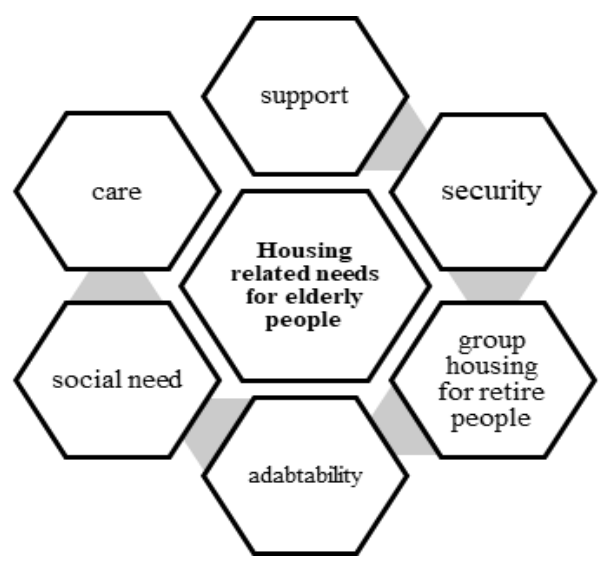

Figure 1 Housing related needs for Elderly in Malaysia (Peace, 2002)

To ensure the welfare of ageing population, there is a remarkable need for a well-developed strategic planning at the government level and among centres operators. There is a need to opt some innovative techniques to overcome the ageing population issues such as promoting the new approaches, systems, products and technologies that accelerate the care process of ageing population (Syed at al., 2012; Cohoon et al., 2010; Mohd et al., 2015; Samad et al., 2017), for their better life standard as elderly population in Malaysia are confronting various health, non-health and societal issues. Below mentioned the discussion on issues of elderly population in Malaysia.

\subsection{Issues Of Elderly Population In Malaysia}

The elderly population in Malaysia is confronting various health, non-health, and societal issues concerning economical aspects, residential aspects, care issues, family support, community care, and education. Therefore, Malaysia requires better health care facilities, along with an active lifestyle for the elderly. The ageing population in its prime has played a role for the nation, and it is a compulsion for the nation to provide them with proper assistance, help, and care, with the utmost attention (Olivia et al., 2016). The other factors that affect the quality of aged population life apart from medical care; are work, family, housing, income, social circle, and leisure activities. As the satisfaction of life is closely related to income and health status, work is also considered vital as it keeps the elderly active at home and in the society. Hence, continued employment can enhance their morale, happiness, and help them in the creation of more extensive social networks (Soon, 2015). Furthermore, the community services such as social clubs, counselling centres, volunteer scheme, home nursing, and transport service will help the elderly to be active in their daily life. Similarly, more awareness sessions for health care of the elderly should be conducted, so that young people at home may be aware of how to help the elderly in time of any need. Therefore, the community can play a drastic role to overcome the challenges of ageing population via awareness program specifically for the older people. The awareness program linked with various sessions consisting of skills, learning how to cope up with living conditions, health-related issues, and healthy life with lesser income. Hence, there should be some pre-retirement programs for the older population to assist them in planning their financial, health-related, and maintenance issues (Lim et al., 2013; Soong et al., 2016). The family members must also be aware of how to deal with older people problems by providing the knowledge on services and resources available in the community. However, policy makers, planners, and politicians, need to be educated in terms of treating the elderly population with more care. In this regard, they must recognize how the ageing processes, what the elderly needs, and how to help them in a better way. Figure 2 shows the significant obstacles confronted by ageing population in Malaysia that have been mentioned in previous studies. 


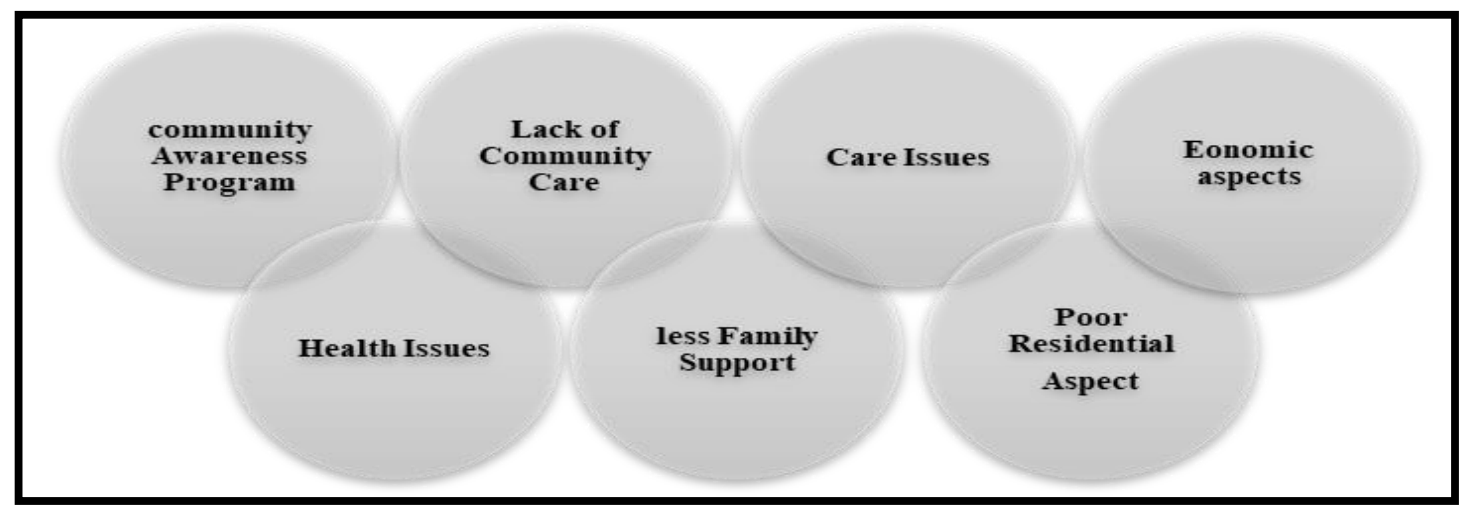

Figure 2 Obstacles confronted by Ageing Population in Malaysia

(Researcher's adaptation from Literature)

In order to overcome the issues of ageing population, Malaysia requires policy revision specifically in place of the ageing population; and there is a dire need to involve the private sector as a partner, and develop strong linkages between policy planners, administrators, services implementer, researchers, formal and informal care system, older and young individuals, and most probably the women entrepreneur who comprises of half of population of Malaysia, and owned 15\% of businesses in Malaysia. Thus, women entrepreneur entry in ageing centres business will bring a drastic change in care centre business, country progress, and empowerment of women (Vannucci et al., 2017; ACP, 2018).

\subsection{Malaysian Women Entrepreneur As Caregiverpreneur (Silver Bullet For Ageing Population)}

Entrepreneurship is a growing trend over the last years, and it is gaining importance worldwide (Tart, 2009). In line with this, women entrepreneurs are also increasing all across the globe. Traditionally, women-owned business venture is evident in health care and service industries, later it transfers to construction (30\%), agro services (24\%), and in transportation (20\%) (Bush et al., 2004; Aini et al., 2017). In nearly all situations, Malaysian government encourages the women entry in entrepreneurial business as various programs organized by the Ministry of Women, Family and Community Development targeting to enhance the women participation in entrepreneurship. The programs such as Single Mother Skill Incubator (I-KIT), Women Entrepreneurs Incubators (I-KeuNita), Women Capacity Development Program, Women Entrepreneur Launching Grant, and Women Taxi Program-(OECD, 2012; Hagen et al., 2013; Aini et al., 2017) are designed to cater to the women business segment. This shows that the Malaysian government is actively taking part in various programs to activate the country's womenfolk to initiate their business. The government of Malaysia continues to focus on the formulation of national policy to ensure the women involvement in place of business advice, financial funding and entrepreneurial skills development (Bank Negara Malaysia, 2005; Ong et al., 2017). The public and private sectors, both are offering programs to enhance the entrepreneurial skills of women by organizing a different program that not only covers the business skills, but also trains women in technical expertise (Farida, 2004; The Star, 2010, Ursulica, 2016; Aini et al., 2017). In line with this, the Federation of Women Entrepreneurs (FEM) and National Association of Women Entrepreneurs Malaysia (NAWEM) have offered the networking opportunities and entrepreneurial skills development programs to equip the women with knowledge and competency required to initiate their businesses.

For years, the Malaysian women entrepreneurs are running various types of business ventures such as saloons, garments, child day care, massage centres, consultant, financial, marketing advisors, retailing, etc., and they are now at the initial phase of involving in the care centre business. However, women entrepreneurs are working diligently for sustainability of their entities, to showcase their novel contribution to the elderly since men are easily trusted by the society. Hence, few women are running the old homes in various states of Malaysia as a sole-proprietor while majority of them running the business in partnership. As the women comprise of half of the population of Malaysia, the economic development of Malaysia is not possible without the involvement of women (Aini et al., 2017; Keyes et al., 2017). It is high time for women entrepreneurs to involve in the ageing care business sector since the nature of work and responsibility at the care centre seem to match well with their personality traits and delicate characters as compared to men (Brindly, 2016; Gupta, 2018). For instance, patience and delicate treatment of the elderly patients are utmost important, and God has bestowed these traits upon women in general (Rashid et al., 2015; Lee et al., 2012). Previous researches show that women entrepreneurs are redesigning the modern business face as they are working forefront in the service sector (Aini et al., 2017) which is considered the most growing sector of the Malaysia's economy. In many situations, women initiate a business entity and involve other women in the business by offering them jobs, and thus opening new job avenues for other women.

Women entrepreneurship has shown greater importance to entrepreneurial research as it has contributed towards both academic and performance (Wennekers et al., 2006; Frear, 2007). Keeping in view of the current scenario of developing country like Malaysia, women entrepreneurship is considered as the primary tool to bring female empowerment via access towards business loans, where the informal business venture is considered as the most affordable path to run a business (Rahman et al., 2012). In the USA economy, women business owners are considered as the new face of the economy, and it depends on the empowering the women through business ventures or entrepreneurial growth. As developed countries, all around the world are straggling towards the appalling problem of underemployment (Mustafa et al., 2008), entrepreneurs with their small business ventures may act as a driving force against this underemployment by breaking the brutal poverty circle by massive employment opportunities, and will act as a catalytic agent for economic prosperity and overall development (Srivastva, 1994; Aini et al., 2017). In this regard, the rise of women empowerment via entrepreneurial skills will 
open new avenues for better living standards and economic prosperity, as women are easily motivated, enthusiastic, and possess broader vision in some business ventures (Gupta, 2018). Hence, women entry in care centre business will act as a rising star for Malaysian economy as the country is experiencing ageing population challenges, and estimates revealed that Malaysia would be in the line of ageing population country until the year 2028 (ACP, 2018). From the cultural perspective, Malaysia is a Muslim country whereby norms and values regarding elderly support and care is very strong. However, the changing trend and mobility from rural to urban areas have transformed the joint family system to nuclear family system. This is causing problems for family members to take care of the elderly due to active involvement of women in the job markets. Thus, the need of ageing care centres are increasing, and the demand for conducive centres are also increasing which leads to insufficient number of centres in Malaysia. As a consequence, Malaysia requires a better support system for the elderly by ensuring better self-respect of the elderly, and providing a better lifestyle, and it is obligatory for the nation to provide the appropriate assistance, help, and care for this delicate customer segment (Olivia et al., 2016; Soong et al., 2016). Thus, women entrepreneur operators of ageing care centres will act, as a silver bullet (immediate solution) to overcome the ageing tsunami that may crash the social comfort of Malaysians in years to come, as more women enter the ageing care centre business, and they help the government to overcome the relentless ageing population challenges. The present study will be useful for the policy makers to formulate policies and procedures to promote the women entrepreneurs' entry in the care centres business ventures to subside the ageing tsunami. Nonetheless, entry of more and more women entrepreneurs in care centres business is the need of hour as women constitute about half of the entire population of Malaysia, and they can play a vital role in the overall development and progress of the country, and will subsequently facilitate the government in overcoming the challenges of the ageing population (Syed et al., 2012; OECD, 2012; Hagen et al., 2013; Ursulica, 2016).

\subsection{RESEARCH OBJECTIVE}

To explore the current situation of ageing care centres run by women entrepreneur in Malaysia.

\subsection{RESEARCH QUESTION}

How women entrepreneur operators in Malaysia manage ageing care services?

\subsection{METHODOLOGY}

The methodology adopted plays a remarkable role in overcoming the issues arising while conducting the research related to entrepreneurship. This study has taken a qualitative research strategy. Qualitative research methodology deals with marketing research method, which emphasised on getting the data via a semi-structured interview technique. Thus, for any research methods, philosophical underpinnings are of utmost importance as it shows the researcher's stance while researching, as it is the entire schema of the research regarding data collection and analysis (Hall et al., 2016). In line with this, Clough et al. (2012) stated that questions that are under investigation are the central pillar of the research study. Keeping in view, the present study considers the interpretive philosophical stance as interpretivism is associated with the experience of people. This philosophy concerns about individual's interaction with society (Creswell, 2013). Five women entrepreneurs who are running ageing care centres in several leading states of Malaysia were interviewed. The interviews was conducted in English from June 2018-December 2018, and tape-recorded for transcription process. The interview lasted about 45 minutes to 1 hour. The semi-structured interviews consisted of following questions about the women entrepreneurs experience as care centres. The study consists of one to one audio-recorded interviews with five participants from five different centres in Malaysia. Thus, for the five interview questions, transcription of each interview question was proceeded into traceable chunks and coded by participants' word of mouth and issues highlighted in the literature. This study adopts the methodology of Moustakas (1994) 7-step technique, which has been adapted from Van Kamm's (1966) methodology for qualitative data analysis (Hall, 2016; Creswell. 2012; Meriam et al., 2014). Table 1 demonstrates the interview questions.

\section{Table 1 Interview Questions}

\begin{tabular}{|l|l|}
\hline \multicolumn{2}{|l|}{ Semi structured interview Questions } \\
\hline 1 & How is your experience in Managing this centre? \\
\hline 2 & In your opinion, what are the problems of the elderly in Malaysia? \\
\hline 3 & Have you ever come across any problematic situation in managing this centre? \\
\hline 4 & Have you ever become frustrated and demoralized by your job nature? \\
\hline 5 & What do you say about Malaysian women should join the elderly care business? \\
\hline
\end{tabular}

\subsection{DESCRIPTIVE FINDINGS}

Table 2 shows the profile of the participants. The details show that out of 5 participants, 2 of them belong to age group 55-60 years, whereas two belong to age group 40-45 years, and one belongs to age group 35-40 years. Regarding qualification, two of the participants have a Master's degree, and the remaining three have diploma certification. All of the participants skewed towards Malay ethnicity. Three 
of them running the centre as the sole ownership and one is running under group partnership. In line with this, all of the centres have caregiver, cook and supporting staff, such that two of the centres (EC \& EA) have about 20-26 caregivers, and all of them have at least one medical doctor and support staff. The strength of male elderly is more significant in number in each centre as compared to female. The age of the elderly in centres skewed towards 50-99 years in four centres, whereas in one centre (EB), age of elderly highlighted from 45-99 years. The monthly expense is three centres (EA, ED, and EE) ranging from RM30000 to 32000, whereas one of the centre (EB) depicts the monthly cost of RM88000 and other centre (EC) shows RM180000. The main income generation of the majority of the centres (EA, EC, ED and EE) are from the customer fees. Regarding financial support, three of the centres shows no support (EA, EC and EE) in terms of donations, whereas two centres (EB, EF) reported that they are receiving donations. The two centres (ED, EE) reported nil for other activities involvement. However, one of the centres involved in renting facilities, and selling consumable medical items and nonmedical services (EA, EC). The fee of all centres shows different packages depending upon the condition of elderly and services requirements, ranging from RM3000 - 6000 and RM900 - 1800, RM3200 - 4000 and RM1650. The four centres (EA, EB, EC and EE) stated "yes" in terms of monthly salary of business operator, whereas one (ED) of the centres take it as non-applicable. The type of employment mostly skewed towards permanent, and one of the centres stated the kind of job is contractual. Regarding governmental support, two of the centres (EA and EE) reported that they are receiving no governmental funding, whereas two (EC and ED) said that they have applied for governmental funding but failed. However, only one of the centre is receiving financial support from JKM (EB) yearly, whereas from MIAS on a monthly basis. Regarding objective behind opening a centre, two of the participants (EC and EE) explain it as a passion whereas (EA, ED) consider elderly care as a responsibility and solution of all problems of elderly.

Table 2a Profile of interviewed participants

\begin{tabular}{|c|c|c|c|c|c|c|c|c|c|c|}
\hline Entrepreneur & Age & Education & Ethnicity & $\begin{array}{c}\text { Year of } \\
\text { Est }\end{array}$ & Centre Type & No. of Staff & $\begin{array}{l}\text { No. of } \\
\text { Elderly }\end{array}$ & $\begin{array}{l}\text { Age of } \\
\text { Elderly }\end{array}$ & $\begin{array}{c}\text { Years of } \\
\text { Operation }\end{array}$ & $\begin{array}{c}\text { Monthly } \\
\text { Expenses }\end{array}$ \\
\hline EA & 43 & $\begin{array}{c}\text { Nurse } \\
\text { certificate }\end{array}$ & Malay & 2008 & $\begin{array}{c}\text { Sole } \\
\text { ownership }\end{array}$ & $\begin{array}{l}\text { Caregiver - } 26 \\
\text { Doctor - } 1 \\
\text { Support staff - } 4 \\
\text { Cook - All staff }\end{array}$ & $\begin{array}{l}\text { Male - } 9 \\
\text { Female - } \\
13\end{array}$ & $58-90$ & 10 & $30,000.00$ \\
\hline EB & 58 & Diploma & Malay & 2007 & Group & $\begin{array}{l}\text { Caregiver - 11 } \\
\text { Support staff - } \\
12 \\
\text { Cook - } 3 \\
\text { Clerk - 3 } \\
\end{array}$ & $\begin{array}{l}\text { Male - } 66 \\
\text { Female - } \\
30\end{array}$ & $45-93$ & 11 & $88,000.00$ \\
\hline $\mathbf{E C}$ & 37 & $\begin{array}{l}\text { Master } \\
\text { (MBA) }\end{array}$ & Malay & 2016 & $\begin{array}{c}\text { Sole } \\
\text { ownership }\end{array}$ & $\begin{array}{l}\text { Care giver - } 20 \\
\text { Doctor - } 2 \\
\text { Support staff - } \\
15 \\
\text { Cook - } 2 \\
\text { Clerk - } 2\end{array}$ & $\begin{array}{l}\text { Male - } 17 \\
\text { Female - } \\
24\end{array}$ & $50-97$ & 2 & $180,000.00$ \\
\hline ED & 46 & Masters & Malay & 2011 & $\begin{array}{c}\text { Sole } \\
\text { ownership }\end{array}$ & $\begin{array}{l}\text { Caregiver - } 6 \\
\text { Support Staff - } 2 \\
\text { Cook - } 1 \\
\text { Physiotherapy - } \\
1\end{array}$ & $\begin{array}{l}\text { Male - } 9 \\
\text { Female - } \\
8\end{array}$ & $53-99$ & 7 & $30,000.00$ \\
\hline $\mathbf{E E}$ & 54 & Diploma & Malay & 2013 & Group & $\begin{array}{l}\text { Caregiver - } 7 \\
\text { Support Staff - } 4 \\
\text { Cook - } 3 \\
\text { Physiotherapy - } \\
1\end{array}$ & $\begin{array}{l}\text { Male - } 33 \\
\text { Female - } \\
13\end{array}$ & $55-98$ & 5 & $32,000.00$ \\
\hline
\end{tabular}

Table 2b Profile of interviewed participants

\begin{tabular}{|c|c|c|c|c|c|c|c|c|c|}
\hline $\begin{array}{c}\text { Entrepre } \\
\text { neur }\end{array}$ & $\begin{array}{c}\text { Main } \\
\text { Income }\end{array}$ & $\begin{array}{c}\text { Consta } \\
\text { nt } \\
\text { Source } \\
\text { of } \\
\text { Income }\end{array}$ & $\begin{array}{c}\text { Financial } \\
\text { Support }\end{array}$ & $\begin{array}{c}\text { Involve } \\
\text { Other } \\
\text { Activity }\end{array}$ & $\begin{array}{c}\text { Fee for } \\
\text { Elderly }\end{array}$ & $\begin{array}{c}\text { Operat } \\
\text { or } \\
\text { Receiv } \\
\mathbf{e} \\
\text { Month } \\
\text { ly } \\
\text { Salary }\end{array}$ & $\begin{array}{c}\text { Type of } \\
\text { Employme } \\
\text { nt }\end{array}$ & $\begin{array}{c}\text { Financial } \\
\text { support } \\
\text { From } \\
\text { Government }\end{array}$ & $\begin{array}{c}\text { Main Objective } \\
\text { Opening a Centre }\end{array}$ \\
\hline EA & $\begin{array}{c}\text { Fee from } \\
\text { family and } \\
\text { patient }\end{array}$ & Fees & Nil & $\begin{array}{c}\text { Renting } \\
\text { facilities }\end{array}$ & $\begin{array}{c}\text { RM } \\
1,650.00\end{array}$ & Yes & Permanent & No & $\begin{array}{c}\text { Solution of all elderly } \\
\text { problems. }\end{array}$ \\
\hline EB & $\begin{array}{c}\text { RM33,000 } \\
\text { (JKM and } \\
\text { MAIS) }\end{array}$ & No & $\begin{array}{c}\text { NGOs } \\
\text { RM10,000 } \\
\text { Yearly }\end{array}$ & $\begin{array}{c}\text { Nur } \\
\text { Ehsan's } \\
\text { Correctio } \\
\text { nal } \\
\text { Workshop }\end{array}$ & $\begin{array}{c}\text { RM300 to } \\
\text { RM1500 } \\
\text { Applicabl } \\
\text { e to no } \\
\text { care taker }\end{array}$ & Yes & Contract & $\begin{array}{c}\text { JKM (yearly) } \\
\text { MAIS } \\
\text { (monthly) }\end{array}$ & $\begin{array}{c}\text { Responsibility comes } \\
\text { on public especially } \\
\text { for old people who } \\
\text { have nobody to take } \\
\text { care them. }\end{array}$ \\
\hline EC & $\begin{array}{c}\text { Fees from } \\
\text { customer }\end{array}$ & Fees & Nil & $\begin{array}{c}\text { Consuma } \\
\text { ble } \\
\text { medical } \\
\text { item and } \\
\text { non- }\end{array}$ & $\begin{array}{c}\text { RM } 3000 \\
\text { to } 6000 \\
\text { (depend } \\
\text { on care } \\
\text { type) }\end{array}$ & Yes & $\begin{array}{c}\text { Permanent, } \\
\text { Contract, } \\
\text { Voluntary }\end{array}$ & $\begin{array}{c}\text { No , but been } \\
\text { applied from } \\
\text { government }\end{array}$ & $\begin{array}{c}\text { Passion and to build } \\
\text { the best and } \\
\text { affordable } \\
\text { environment for } \\
\text { elderly needs. }\end{array}$ \\
\hline
\end{tabular}




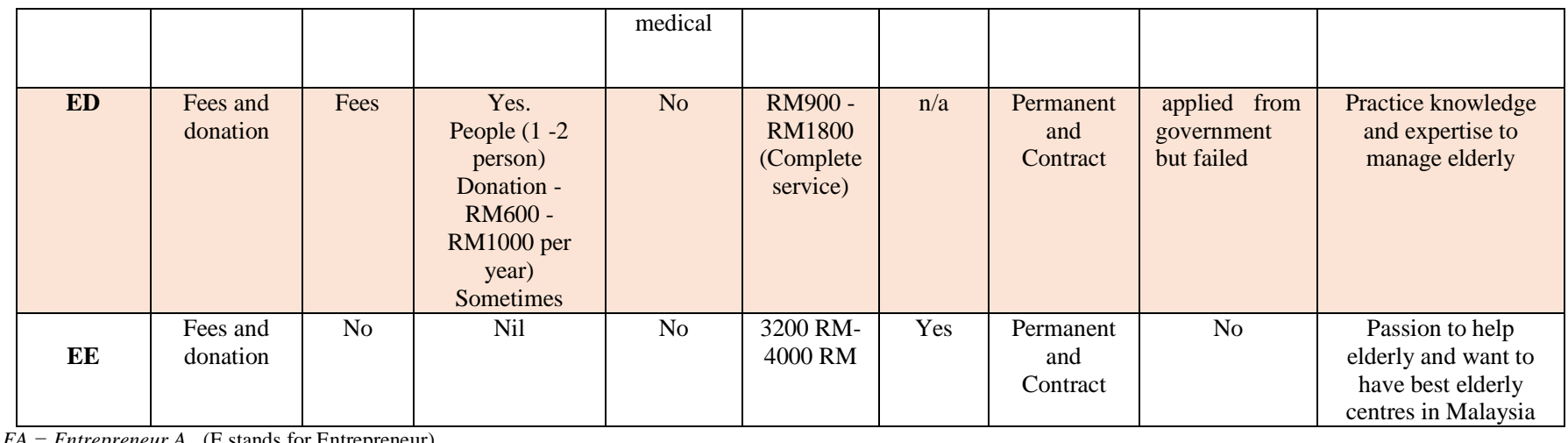

$E A=$ Entrepreneur $A \quad$ (E stands for Entrepreneur)

\subsection{DISCUSSION}

The interview process was taken into account for analysing the current situation of women entrepreneurs in ageing care business and difficulties faced by them. Hence, coded data from each interviewed respondent was cross-referenced with another participant in order to locate the similarities and dissimilarities among the participant's views particular. Crotty (1998) stated that the continuous comparison results in lesser number of themes for a research question. Table 3 explains the generated themes from the transcribed interview under interview questions.

Table 3 Themes generated

\begin{tabular}{|c|c|c|}
\hline Interview Questions & Themes & No of participants \\
\hline \multirow[t]{3}{*}{ 1. How is your experience in Managing this centre? } & Difficult & 4 \\
\hline & Challenging & 5 \\
\hline & Struggling & 3 \\
\hline \multirow[t]{8}{*}{ 2. In your opinion what are the problems of elderly in Malaysia? } & Less family support & 4 \\
\hline & Care Issues & 5 \\
\hline & Loneliness & 5 \\
\hline & Dementia & 5 \\
\hline & Lack of facilities & 3 \\
\hline & Health Issues & 4 \\
\hline & Poor residential Aspects & 4 \\
\hline & Lack of Community Care & 5 \\
\hline \multirow{8}{*}{$\begin{array}{l}\text { 3. Have you ever come across any difficult situation in managing } \\
\text { this centre? }\end{array}$} & Funding & 5 \\
\hline & Licensing Issues & 3 \\
\hline & $\begin{array}{c}\text { Dealing with elderly's family } \\
\text { members }\end{array}$ & 5 \\
\hline & Lack of trained staff & 4 \\
\hline & Staff retention & 4 \\
\hline & $\begin{array}{l}\text { Lack of governmental } \\
\text { funding }\end{array}$ & 5 \\
\hline & Less technology & 3 \\
\hline & No banking support & 2 \\
\hline \multirow{3}{*}{$\begin{array}{l}\text { 4. Have you ever become frustrated and demoralized by your job } \\
\text { nature? }\end{array}$} & Noble cause & 5 \\
\hline & Time constraints & 5 \\
\hline & Hectic & 4 \\
\hline
\end{tabular}




\begin{tabular}{|c|c|c|}
\hline & Responsibility & 4 \\
\hline \multirow{5}{*}{$\begin{array}{l}\text { 5. What do you say about Malaysian women should join elderly } \\
\text { care bsuiness and Why? }\end{array}$} & Responsible & 4 \\
\hline & Caring & 3 \\
\hline & Hardworking & 5 \\
\hline & Patience & 5 \\
\hline & Tolerance & 5 \\
\hline
\end{tabular}

Pertaining to Question 1 regarding experience in managing the centre, majority of the participants considered it as challenging, and this finding is in line with previous researches (Merriam et al., 2014; Rashid et al., 2015). One of the feedback from the participant is stated below:

"My experience I will say is very difficult, full of challenges, hard work and complications. I struggled a lot and worked day and night. Sometimes, my family was also neglected at that time, the biggest challenge I faced in getting Licensed and initial funding. I asked help from my family and friends circle" (Participant EE).

Relating to Question 2 regarding opinion about problems of elderly in Malaysia, majority of the participants highlighted about care issues, loneliness, dementia, followed by health and poor residential aspects which are also indicated in previous studies (Akil et al., 2014; Tohit et al., 2012; Hagen et al., 2013). One of the feedbacks from the participant ED is provided below:
"We are not getting a donation from the governmental side in monetary terms. In my centre, I always try to accommodate the elderly if someone is not able to pay full fees. We are not getting profit just sustainable. I feel financial constraints, and lack of technology and lack of trained staff is the biggest hurdle" (Participant ED).

Concerning to Question 3 regarding difficult situation in managing the centre, most quoted difficulties are funding, dealing with elderly's family members, lack of governmental funding, followed by lack of trained staff, staff retention, and licensing issues as previous researches also agreed (Lee at al., 2012; Rashid et al., 2015). One of the participants (EB) stated as follow:

"The biggest issue is staff retention, we trained the staff, and they sometimes left without intimation, the elderly people are just like a small child. They are attached to the staff and sudden the staff left. Then it became difficult for us to manage. The elderly care is all about love, care and attention so staffing is the biggest issue" (Participant EB).

Pertaining to Question 4 regarding frustration and demoralization with the job nature, majority of the participants reported hectic, time contraints and big responsibility as explained in previous reseraches (Merriam et al., 2014; Aini et al., 2017). Participant EC commented:

"I have two daughters, and I used to give full time to my centre, as I do not rely much on staff. I considered it as a noble cause too. Sometimes my routine becomes very hectic, and I get demoralized with issues such as staffing, budgetary constraints, funding. My friends circle supportive always encouraged me whenever I feel like demotivated because of issues and problems in running the centre" (Participant EC).

Concerning to Question 5 regarding opinion on whether or not Malaysian women should join the elderly care bsuiness, majority of the participants pointed out that malaysian women are hardworking, have patience and tolerance, followed by responsible and caring nature, which also highlighted in the previous studies (Brush et al., 2006; Aini et al., 2017). As participant EA mentioned;

\footnotetext{
"Women should come in this business of ageing care centre and elderly need utmost attention, love and care. Women are, by nature, delicate and supportive and feel other problem better than man feels. Patience and tolerance in women personality are more from the nature side. Women should step in as the majority of our nurses are retired wasting their talent; they must come in this business" (Participant EA)".
}

Above mentioned the feedbacks from the participants pertaining to the research questions. The majority of the participants highlighted difficulties such as less technical and administrative skills, financial constraints, lack of adaptation of innovative techniques along with proper marketing strategies and tools. Most of the Centre are getting donations in the form of food items not in the monetary terms, this is main issue highlighted by entrepreneurs during the interview. They are happily accepting the food items donations but still lacking in monetary donations. They are not getting any contribution from the governmental side or any other third party. The donation they are getting just in the form of staple food materials such as rice, flour, sugar and dry eatables although women entrepreneurs are facing difficulties such as funding, licensing issues, less technology, staff retention, and lack of trained staff. Despite all the flaws, women entrepreneurs seem to have much potential and they are capable of running the care centre on sustainability base. The main challenge, which Malaysia is facing, is planning and dealing with an ageing population, as, by $2030,15 \%$ of Malaysian population will be above 60 
years of age. Women entrepreneurs in this business sector need well-developed strategies to provide good care services to the elderly customer segment.

As several participants revealed that the main objective behind their initiation of elderly care centres is to get the best possible solution for all elderly problems, thus, the implement of a proper standard of procedures is essential in all the elderly care centres. The findings of the study regarding difficulties and the current situation of women entrepreneurs in ageing care centres in Malaysia are summarized in Figure 3. However, Researchers should give importance to the topic of the ageing population in overcoming the issues concerned with older people for a better quality of life and to lessen the elderly dependency on government and society to care for them. In this regard, the young people to be aware of the caring community and teach a positive feeling among them regarding older people care and help. This practice will lead to healthy ageing in reality (Vannucci et al., 2017; ACP, 2018).

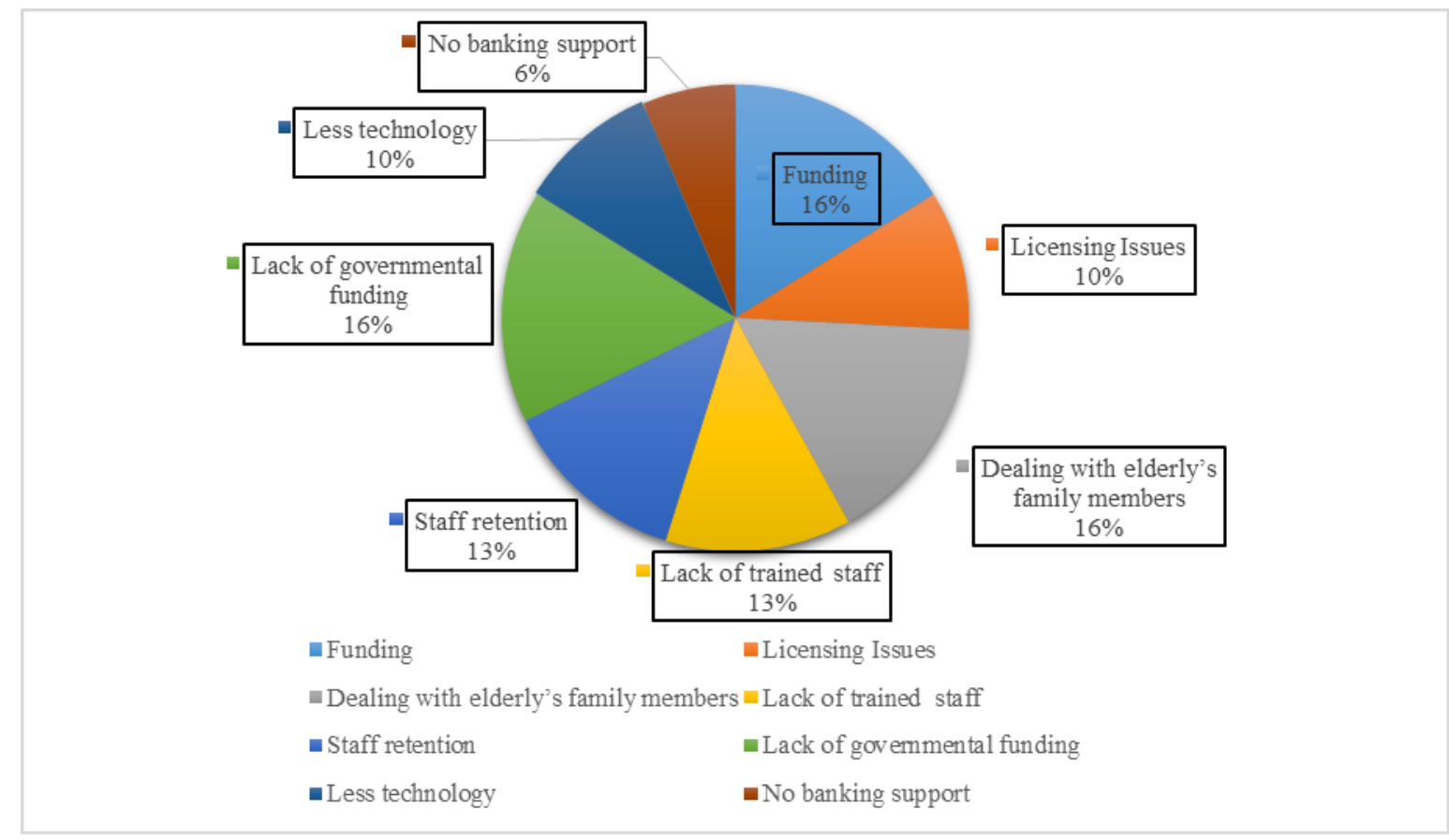

Figure 3 Difficulties in Managing Ageing Care Centres

(Source: Present Authors)

\subsection{RECOMMEDATIONS}

While considering the difficulties which women entrepreneurs are facing in running ageing care centres in Malaysia at present, the following recommendations on the additional roles and responsibilities of various stakeholders such as government, banks, families and ageing care centre administration on the development of conducive elderly care centres have been proposed. The recommendations can mediate some of the difficulties and challenges face by the entrepreneurs in dealing with the elderly issues.

\section{Government}

- The government should take necessary actions regarding annual funding to ageing care centres. This will help them to overcome financial constraints to some extent as currently these centres are working on sustainability basis without any profits.

- The government personal should do a surprise visit to centres to monitor the offered services to maintain quality standards in ageing care centres offerings and services. It will help in gain the trust of elderly people families and they may leave their parents in care centres with satisfaction.

- There should be an allocation of special funds for senior citizens of society from Ministry, so that they may not be dependent on their families for their basic needs.

- There must be an entrepreneurial training program specifically for women entrepreneurs of ageing care centres to enhance their technical and administrative skills. This will help the women entrepreneur to enhance their abilities and selfconfidence.

- Government should come up with standard ageing population policy for welfare and wellbeing of ageing population in terms of health, pension, elderly care and categorization of productive and non-productive elderly group. 


\title{
Banks
}

- The banking sector should take necessary action to make the process simpler for loans specifically for care centres entrepreneurs. It will help them in the extension of business entities. As Malaysia is in need of well -developed ageing care centres for well-being of elderly population.

- The banking sector should take elderly care issue seriously and initiate funding programs in terms of elderly care irrespective of Muslims or non-Muslims category. This funding program will help the elderly who have no family members to support them specifically.

- Proper banking support is required specifically for those care centres where if one elderly is paying the fees, next two are living free and getting the same facilities, care and attention.

\section{Community}

- Awareness program for the younger population and life options arrangements for the ageing population is the need of the hour. As children should be educated from preschool and elementary classes with elderly care course. This will help to prepare them to absorb the elderly care in future. More awareness sessions on challenges and social responsibility for ageing population in the communities, neighborhood, and country at large that involve the children, youth, and older generations. This program should be aired or publicized in electronic media, social media and printed media on a continuous basis.

\subsection{THEORETICAL JUSTIFICATION}

\author{
Sustainability Entrepreneurship Theory
}

The environmental and social issues such as elderly issue, nowadays are greater in number all across the globe. Due to which many industrialised countries are facing the challenge of unemployment from increased globalized economy and society. Therefore, sustainability is considered as a pattern, which can be treated as the main point for the solution of today's societal and environmental challenges (Hardin, 1968; Kirzner 1985; Venkataraman, 1997; Shane and Venkataraman, 2000). Past researches demonstrated the linkages between overall economic behaviour, management and sustainability, which ultimately result in success (Aragon et al., 2003; Lenox, 2006). Hence, from the entrepreneurship perspective it depicts how the economic sustainability behaviour turns the entrepreneurial opportunities to be quiet fruitful. Furthermore, the fundamental and essential innovation are often emerge from entrepreneurial ventures, which contributes greatly towards sustainable development (Cohen et al., 2008; Marcati et al., 2008). Thus, the women entrepreneur in ageing industry may considered as one of the most important input for overall economic development of the country to accelerates the economic activities by taking the entrepreneurial decisions for the wellbeing of ageing population as country will be in line of ageing countries until the year 2028 .

\subsection{CONCLUSION}

The longer life span, trade and industry development, family environment are creating various challenges specifically in place of finances, care, support, social security for older people. The question arises with only slightly more than a decade to go, how ready Malaysia in overcoming the issues related to the ageing population? Previous studies implicate that the needs of elderly segment are almost similar to disabled persons since they then to be very delicate, sensitive, dependent, easily fall sick, seeking attentions, and showing childlike behavior almost at all times. As a consequence, they might end up staying at elderly care centre to get better service which their children cannot provide at home. Due to the increasing demand of elderly care centres, women entrepreneurs' role and tasks are getting more challenging to cater to this special segment. Findings of this study revealed that the women entrepreneurs of ageing care centres are confronting various problems such as lack of funding, less trained staff, licensing issues, and staff retention. Even then, they are running the centres on a sustainability base and this depicts that they do have potentials to grow in the business. One of the key reasons behind their capability of running the care business lies on their character and personality attributes i.e. patience, empathy, sympathetic, etc. that fit with the demand of the ageing industry. With more and more women entrepreneurs' entry in the ageing industry, they can act as a silver bullet to help the government to overcome the tsunami of the ageing population in Malaysia.

In order to help the women entrepreneurs to grow well in the elderly care business sector, more supports from various stakeholders i.e. family, government, banking sector, and community should be provided to them either directly or indirectly which will subsequently affect the country's social wellbeing. This study will eventually help the policymakers to formulate strategies for women entrepreneurship in Malaysia, especially the care centre entrepreneurs, and the entrepreneurs themselves can use the information from this study to further improve their services to the targeted customers, both elderly and their family. It is notable that elderly issues such as dementia, delicate feelings, sickness etc. should not only become the elderly family's main concern but the community and society in general should also aware about the delicate issues and be more understanding and caring to the elderly's problems and needs. With better awareness and support relating to elderly wellbeing, it is hope that Malaysia may transform to be a caring nation for the ageing population. The findings of this study will add to the stream of literature on women entrepreneurship in elderly care business sector which will lead to more related research endeavors to be undertaken in the future. Since this study is limited to five centres, and involved the Malay women entrepreneurs only, future studies may be conducted to add more centres throughout Malaysia, and cover women entrepreneurs from other ethnicities to get a holistic view of the entrepreneurship and ageing population issue in the country. 


\section{References}

Aini, Suzana -Ariffina, Sahdiya-Mohamed Saleh, Baqutayanb, Akbariah M. Mahdzirc (2017): Enhancing Women Entrepreneurship Development Framework: Policy \& Institution Gap and Challenges in the Case of Malaysia: Journal of Science, Technology and Innovation Policy, 3(2), 1-12

Jacqueline WM Wong, Azhar Hew, Bryan Zeng (2017) Advance Care Planning, Conversation about your Future Self and Care Management and Finance (2018, October). Retrieved from: http://www.agedcare.com.my/acgconcept/.2017/July/Caregiverpreneurs. Access date: 23 August 2018

Akil, S. M. S., Abdullah, S., \& Sipon, S. (2014). Challenges In Managing Elderly Care Centers In Malaysia.International Journal of Arts \& Sciences, 7(3), 129.

Andersen, J. P., Prause, J., \& Silver, R. C. (2011).A Step- by- Step Guide to Using Secondary Data for Psychological Research. Social and Personality Psychology Compass, 5(1), 56-75

Aragon-Correa, J.A., Sharma, S., (2003). A Contingent Resource-Based View Of Proactive Corporate Environmental Strategy. Academy of Management Review, 28(1), 71-88

Bank Negara Malaysia. (2005). Enhancing Capacity And Capability of SMEs. Retrieved 2 July 2014 from http://bnm.gov.my/files/ publication/sme/en/2005/chap_5.pd.

Bauer, R.A and Gergen, KJ (1968). The Study of Policy Formation. New York. The Free.

Boslaugh, S. (2007). Secondary Data Sources For Public Health: A Practical Guide. New York, NY: Cambridge.

Brindley, C. (2016). Barriers to Women Achieving Their Entrepreneurial Potential : Women and Risk. International Journal of Entrepreneurial Behavior \& Research Article information :, (April 2005). https://doi.org/10.1108/13552550510590554.

Brush, C. (2006). Forthcoming. Women Entrepreneurs: A Research Overview. In The Oxford Handbook of Entrepreneurship, Basu A, Casson, MC, Wadeson, N, Yeung, B (eds).

Burton, C. (2016). Livability for All: The 2016 AARP Age-friendly Community Survey of Tallahassee, Florida AARP Members and Residents Age 50-Plus. American Association of Retired Persons. Retrieved 16 September 2016 from http://www.aarp.org/content/dam/aarp/research/surveys_statistics/livcom/2016/2016-afctallahassee-report-rc-liv-com.pdf.Press, 1968.

Chawla, M., Betcherman, G., and Banerji, A. (2007). From Red To Gray: The "Third Transition" Of Aging Populations In Eastern Europe And The Former Soviet Union. Washington DC: The World Bank. doi:10.1596/978-0-8213-7129-9.

Clark Moustakas. (1994). Phenomenological Research Methods - Clark Moustakas - Google Books. https://doi.org/978-0-8039-5798-5

Clough, P., and Nutbrown, C. (2012). A Student's Guide to Methodology: Justifing Enquiry (3rd ed.). London: Sage.

Cohen, B., Smith, B., Mitchell, R., (2008). Toward a Sustainable Conceptualization Of Dependent Variables In Entrepreneurship Research. Business Strategy and the Environment, 17, 107-119.

Cohoon, J. McGrath., Wadhwa, V. \& Mitchell, L. (2010) “Are Successful Women Entrepreneurs Different from Men?" Retrieved May 11, 2010 from http://ssrn.com/abstract=1604653 orhttp:// dx.doi.org/10.2139/ssrn.1604653.

Creswell, J. W., \& Poth, C. N. (2013.). Qualitative Inquiry \&Amp; Research Design : Choosing Among Five Approaches. Retrieved from https://in.sagepub.com/enin/sas/qualitative-inquiry-and-research-design/book246896. Access date: 23 February 2019

Creswell, J. W., \& Poth, C. N. (2014.). Qualitative Inquiry \& Research Design : Choosing Among Five Approaches. Retrieved from https://in.sagepub.com/enin/sas/qualitative-inquiry-and-research-design/book246896 Access date: 23 February 2019

Mohd Uzir Mahidin (2017) Department of Statistic, Malaysia's homepage - Current Population Estimates, Malaysia,2018,https://www.dosm.gov.my/v1/index.php?r=column/ctheme\&menu_id=L0pheU43NWJwRWVSZk1WdzQ4TlhUUT09\&bul_id=OWlxdEV oYlJCS0hUZzJyRUcvZEYxZz09 Date of download: 02.06.2018. Cited in text as: www.dosm.gov.my/b

Farber, N., Shinkle, D., Lynott, J., Fox-Grage, W. and Harrell, R.(2011). Aging In Place: A State Survey Of Livability Policies And Practices. AIP Publishing.

Farida, H. S. (2004). Mainstreaming Potential Women Exporters in International Markets through ICT: Malaysia.Project paperfor "Supporting Potential Women Exporters" CTI 34/2003 T, APEC Committee on Trade and Investment

Fatimah, H., Aznarahayu, R., \& Nasina, M. D. (2014). Rural Women Entrepreneurs In Malaysia: What Drives Their Success? International Journal of Business and Management, 9(4), 10-21. http://doi.org/10.5539/ijbm.v9n4p1

Fausset, C.B., Kelly, A.J., Rogers, W.A. and Fisk, A.D., (2011). Challenges to Aging In Place: Understanding Home Maintenance Difficulties. Journal of Housing for the Elderly, 25(2), 125-141.

Frear, D. (2007). Rural Female Entrepreneurs: A Demographic Survey in Rural Pennsylvania. Journal of Business and Public Affairs, 1(2), 12-21.

Guerin, B., Hoorens, S., Khodyakov, D. and Yaqub, O., (2015). A Growing And Ageing Population. Global societal trends to, 2030.

Hall, E., Chai, W., \& Albrecht, J. A. (2016). A Qualitative Phenomenological Exploration of Teachers'Experience With Nutrition Education. American Journal of Health Education, 47(3), 136-148. https://doi.org/10.1080/19325037.2016.1157532.

Hagen, S.A., (2013). Rising Demand For Long-Term Services And Supports For Elderly People. Congressional Budget Office. Goh, Ban Lee (1988). Future of Urban Planning in Malaysia. Habitat International , 12(4), 5-12. Pergamon Press. UK.

Hardin, G., (1968). The Tragedy Of The Commons. Science, 162, 1243-1248.

Hock, H. and Weil, D. N. (2012) “On the Dynamics Of The Age Structure, Dependency And Consumption”, Journal of Population Economics, Springer, 25, 10191043 .

Kirzner, I.M., (1985). Discovery and the Capitalist Process. University of Chicago Press, Chicago, IL.

Keyes L. ; (2017). Nurse entrepreneur trends Available from: http://www.nurse-entrepreneur-network.com/public/727.cfm. Accessed May 22, 2017.

Kumar, H.K. (2014) At What Cost, Healthcare In Malaysia? The Star Online. Retrieved 17 February 2017 from http://www.thestar.com.my/Lifestyle/Health/2014/11/16/At-what-cost-healthcare-in-Malaysia/.

Lee R. and Mason, A. (2012). Population Aging and the Generational Economy: A Global Perspective. Northampton: Edward Elgar Publishing.

Lenox, M., (2006). The Role Of Private, Decentralized Institutions In Sustaining Industry Self-Regulation. Organization Science, 17 (6), 670-690.

Lim, W. W. X., Sulaiman, N., \& David, B.(2013). Social Care Facilities Management Audit (SCFMA) At The Residential Carehome For The Elderly (RCHfE) in Malaysia.

Marcati, A., Guido, G., Peluso, A.M., (2008). The Role Of SME Entrepreneurs' Innovativeness And Personality In The Adoption Of Innovations. Research Policy, $37(9), 1579-1590$.

Meriam Syed Akil, S., \& Abdullah, S. (2014). Challenges in Managing Elderly Care Centres in Malaysia. International Journal of Arts \& Sciences, 07(03), 19446934.

Mohd Nor, L., Yusof, M., Mohamed, O.E.B., Xavier, S.R., Mirani, M., Mohd Zaini, S. (2015). Women and Family Entrepreneurship in Malaysia: A Formidable Economic Force, CEDAR-SME Bank (ISBN: 978-967-12543-6-3

Mustafa, Z. and Ismailov, N. (2008), "Entrepreneurship and Microfinance: A Tool for Empowerment of Poor - Case of Akhuwat-Pakistan", Master's Thesis, School of Sustainable Development of Society and Technology, Malardalen University.

Tengku Aizan Hamid (2011) National Policy for Elderly.http://www.kpwkm.gov.my/documents/10156/576479be-3a70-4dc0-82dd-0ee30cc83ea8 (8th August 2015). National Population and Family Development Board Malaysia.(2011). Malaysian Population and Family Survey Report. KualaLumpur, Malaysia: Author. OECD (2012). Development Co-operation Report . Retrieved 2 July 2014 from http://www.oecd.org/ mena/investment/47246782.pdf.

Olivia Tan Swee Leng, Shereen Khan, Rossanne Gale Vergara and Nasreen Khan (2016), Journal of SoutheastAsian Research, DOI: 10.5171/2016. Article ID 974366. 2016 (2016), 1-8 pages

Ong, F. S., Phillips, D. R., \& Hamid, T. A. (2009). Ageing in Malaysia: Progress and prospects. Policies and Protections for Ageing Society In Malaysia, 138-160

Ong, S. Y. Y., Habidin, N. F., Salleh, M. I., \& Fuzi, N. M. (2017). Relationship of Entrepreneurship Practice and Business Performance of Women Entrepreneur in Malaysia. International Journal of Academic Research in Business and Social Sciences, 6(11), 95-109. https://doi.org/10.6007/ijarbss/v6-i11/2376. 
Rashid, A., \& Tahir, I. (2015). The Prevalence and Predictors of Severe Depression among the Elderly in Malaysia. Journal of cross-cultural gerontology, 30(1), 6985.

Rehman, S., \& Roomi, M. A. (2012). Gender and Work-Life Balance: A Phenomenological Study Of Women Entrepreneurs In Pakistan. Journal of Small Business and Enterprise Development, 19(2), 209 - 228.

Samad, S., \& Mansor, N. (2017). Population Ageing and Social Protection in Malaysia. Malaysian Journal Of Economic Studies, 50(2), 139-156. Retrieved from https://mjes.um.edu.my/article/view/2873. Access date: 10 October 2018

Shane, S., Venkataraman, S., (2000). The Promise Of Entrepreneurship As Afield Of Research. Academy of Management Review, 25 (1), $217-226$.

Soong et al., (2016) Newsletter of the National Council of Senior Citizens Organisations Malaysia (NACSCOM), Vol.32. Suara Kanan KDN NO PP 10706/09/2008(020548).Printer: Print Wizard Sdn Bhd No. 9, Jalan 17/45, 46400, Petaling Jaya, Selangor Darul Ehsan, Malaysia. Tel: 03-7956 2600.

Soon, S.Y. (2010) Public Versus Private On Medical Care. Borneo Post online. Retrieved 10 October 2015 fromhttp://www.theborneopost.com/2010/12/12/publicversus-private-on-medical-care/.

Srivastava ,R. M, .(1994). Emerging Profile of small women Entrepreneurs cum managers in India: A case Study. Woman in Management: Champions of change, UPI. Dhaka.

Sulaiman, N, Baldry, D and Ruddock, L (2005a) Modes of Formal Housing Provision in Malaysia. Proceeding of the European Real Estate Society(ERES) Conference 2005.June 14-18. University College Dublin, Ireland

Syed Shah Alam., Zizah Che Senik. \& Fauzi Mohd.Jani. (2012). An Exploratory Study Of Women Entrepreneurs In Malaysia: Motivation And Problems. Journal of Management Research, 4(4), 282-297.

Syed Zamberi Ahmad, Xavier, S.R. (2012). Entrepreneurial Environments And Growth: Evidence from Malaysia GEM data. Journal of Chinese Entrepreneurship, $4(1), 50-69$.

Tart, N. (2009). Changing Demographics in Entrepreneurship. [Online] Available: http://ezinearticles.com/?expert (November 10, 2005).

The Star Press. (2010). Right Place, Right Time, Right People. Retrieved 2 July 2014 from http://thestar.com. my/news/strory.asp?file=/2006/7/24

Tohit, N., Browning, C. J., \& Radermacher, H. (2012). 'We Want A Peaceful Life Here And Hereafter':Healthy Ageing Perspectives of older Malays in Malaysia. Ageing and Society, 32(03), 405-424

Tohit, N., Browning, C. J., \& Radermacher, H. (2012). 'We Want A Peaceful Life Here And Hereafter': Healthy Ageing Perspectives Of Older Malays in Malaysia Ageing and Society, 32(03), 405-424.

United Nations Statistics Division (2005), United Nations Statistics Division: Demographic

Ursulica, T. E. (2016). The Relationship between Health Care Needs and Accessibility to Health Care Services in Botosani County- Romania. Procedia Environmental Sciences, 32, 300-310. https://doi.org/10.1016/j.proenv.2016.03.035.

Vannucci, M. J., \& Weinstein, S. M. (2017). The Nurse Entrepreneur: Empowerment Needs, Challenges, And Self-Care Practices. Nursing: Research and Reviews, 7 , 57-66. https://doi.org/10.2147/NRR.S98407.

Venkataraman, S.,(1997). The Distinctive Domain Of Entrepreneurship Research: An Editors' Perspective. In: Katz, J., Brockhaus, J. (Eds.), Advances in Entrepreneurship, Firm Emergence, and Growth. Springer, New York, NY, 141-160

Wennekers, A.R.M. (2006). Entrepreneurship at Country Level, Economic And Non-Economic Determinants, Dissertation, ERIM, Rotterdam.

World Health Organization (2012), "Healthy Ageing", in http://www.euro.who.int/en/what-we-do/health-topics/Life-stages/healthyageing, accessed on 28 November 2012.www.microsoft.com/enus/news/exec/billg/writing/shapingtheinternet.aspx

Yusuff, RM, Abdul Rashid, SN, Hashim, NS (2004), Anthropometry and Quality Housing for the Elderly. National Conference on Affordable Quality Housing. November 24-26,2004, Miri, Sarawak, Malaysia. 